\title{
12. The Tsar and Empire: Representation of the Monarchy and Symbolic Integration in Imperial Russia
}

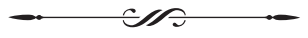

Cymbolic representation played a central role in defining the concept of $\mathbf{N}$ monarchical sovereignty in Russia. In the absence of native traditions of supreme power, Russian tsars invoked and emulated foreign images of rule to elevate themselves and the state elite above the subject population. The source of sacrality was distant from Russia, whether it was located beyond the sea whence the original Viking princes came, according to the tale of the invitations of the Varangians, or fixed in an image of Byzantium, France, or Germany. ${ }^{1}$

The centrality of conquest in the representations of Russian rulers contrasts with the mythical history of the Hapsburg emperors, which legitimized the expansion of imperial dominion through marriage. ${ }^{2}$ From the fifteenth century, when Ivan III refused the title of king from the Holy Roman Emperor with the declaration that he "had never wanted to be made king by anyone," Russian monarchs affirmed and reaffirmed the imperial character of their rule, evoking the images of Byzantine and later Roman and European imperial dominion. Beginning with Ivan IV's conquests of Kazan and Astrakhan, they

1 On the symbolic force of foreignness see Ju. M. Lotman and B. A. Uspenskii, "The Role of Dual Models in the Dynamics of Russian Culture (Up to the End of the Eighteenth Century)," in Ju. M. Lotman and B. A. Uspenskii, The Semiotics of Russian Culture, ed. Ann Shukman (Ann Arbor: Michigan Slavic Contributions, 1984), 3-35.

2 See the interesting comparison by Orest Subtelny between Hapsburg and Romanov empires in "The Hapsburg and Russian Empires: Some Comparisons and Contrasts," in Empire and Society: New Approaches to Russian History, ed. Teruyuki Hara and Kimitaka Matzuzato (Sapporo: Slavic Research Center, Hokaido University, 1997), 86-90. 
sought to realize the imperial vision of rule over extensive realms and other peoples.

Of course, European monarchs also borrowed foreign and imperial images of rule. The distinguishing feature of Russian monarchy was the persistence of a pattern of appropriation of symbols and images from abroad long after it ceased to be the practice in Europe. This pattern has befuddled efforts to categorize the Russian state under a single cultural rubric, Mongol, Byzantine, or European. The devices of identification with foreign sources of power were varied-tales of foreign origin, like the "invitation of the Varangians," or analogies with or imitation of foreign rulers. A national subtheme runs through Russian political imagery and myths, but until the late nineteenth century as an antithesis repeatedly submerged by a dominant foreign motif.

The pattern of representation that emerged in the eighteenth and nineteenth centuries identified the ruling monarch and his servitors with dominant figures of western monarchy. The monarch assumed features of European absolutist rulers, Baroque, Neo-Classical, Napoleonic, presented in scenarios suiting contemporary ideas and tastes. The Russian nobility, lacking traditions of feudal rights or local autonomy, owed their standing, wealth, and influence to service to the sovereign. Joining imperial ceremonies, they displayed their personal bond with the monarch and shared in his sacral aura. They performed his scenarios as cultivated western noblemen and elevated them as Russians capable of appearing as Europeans, above and superior to their subjects, but nonetheless Russians acting the role of Europeans. As Iurii Lotman wrote, it was necessary "not to be a foreigner" but to retain "the outsiders 'alien' Russian attitude to them. One did not have to become a foreigner, but to behave like one." 3

The universalistic westernized forms of representation facilitated the integration of national elites into a multi-ethnic All-Russian nobility, the vserossiiskoe dvorianstvo. As the empire expanded to include Baltic provinces, Cossacks, Muslim khanates, and Georgia, its members took on the westernized culture and manners of the court and participated in its ceremonies. ${ }^{4}$ In this

3 Lotman and Uspenskii, “The Role of Dual Models," 232-33.

4 See Andreas Kappeler, The Russian Empire: A Multi-ethnic History (Harlow, UK: Longman, 2001), 28-29, and passim; on the processes of repression and co-optation in the steppe regions see Michael Khodarkovsky, Russia's Steppe Frontier: The Making 
respect, imperial Russia represents an example of what Ernest Gellner called an agro-literate society-a traditional society organized horizontally, in which the privileged, regardless of ethnic background, sought to separate themselves as much as possible from the lower orders, in this case by assuming western personas. 5

The emperors of Russia elaborated and performed narratives of foreign and imperial origin to display the great distance between rulers and ruled and to dramatize and perpetuate their claims to absolute, transcendent power. The exercise of power and the representation of the monarch in this way proved reciprocal processes: absolute rule sustained the image of a transcendent monarch, the incarnation of the state, which in turn warranted the untrammeled exercise of power. The imperative to appear in the context of myth instilled an aversion to compromise and delegation of authority-to accept intermediaries, such as parliamentary institutions or even a chancellor loyal to the monarch, at times of political crisis. The aversion to constitutionalism reflected merely one aspect of a mentality that knew only absolute domination or utter defeat.

\section{ENLIGHTENMENT AND INTEGRATION}

Catherine the Great envisioned a process of enlightenment of native elites, which, undertaken by the Russian state, would assimilate the diverse nationalities into the secular, westernized culture of the Russian nobility. She adopted V. N. Tatishchev's theory that Russians came from a mixture of various peoples and she expected assimilation to continue by uplifting and instructing native populations. She sponsored ethnographic expeditions and surveys, under the aegis of the Imperial Academy of Sciences, to learn about those peoples of the empire so that they could be transformed into Russians and would be able to "share in their happiness." Catherine's ideas informed the pioneering ethnographic works of the late eighteenth century, particularly Johann Georgi's landmark four-volume Description of All the Peoples Inhabiting the Russian State (Opisanie vsekh obitaiushchikh

of a Colonial Empire, 1500-1800 (Bloomington: Indiana University Press, 2002), 201-10, 225-26.

5 Ernest Gellner, Nations and Nationalism (Ithaca, NY: Cornell University Press, 1983), 11. 
$v$ Rossiiskom gosudarstve narodov). ${ }^{6}$ Georgi asserted that the Russian empire was the most diverse of empires. "Hardly any other state in the world possesses such a great variety of different nations, survivals of peoples, and colonies as the Russian state." 7

But enlightenment promised to efface their indigenous traits. Those at earlier stages, Georgi wrote, the Tungus, the Chukchi, were ignorant, simple, and possessed a beguiling innocence. It was "the uniformity of State organization" that could transform all nationalities into educated, Europeanized Russians. The state, Georgi concluded, was "leading our rude Peoples by giant steps toward the common goal of general enlightenment in Russia, of a wonderful fusion of all into a single body and soul, and of creating, as it were, an unshakable Giant that will stand for hundreds of centuries." It is indicative that the one national group that Georgi omitted from his survey was the Russians: the Russians for him did not represent the peoples "inhabiting the Russian state," who were characterized by a variety of distinctive customs, dress, and religious beliefs, and thereby at a lower level of development than they. When the Russians were introduced in the second edition, which was not authored by Georgi, they were characterized as a "ruling nation." 8

Enlightenment also presumed conversion to Orthodoxy, which was understood to be the first step in the process. ${ }^{9}$ This faith in the power of reason and Orthodoxy to transform backward peoples is suggested by the remarks of a young Russian, M. N. Makarov, who observed a Kalmyk deputy marching among the noblemen to the Assumption Cathedral for the rites of coronation of Alexander I in 1801. The deputy, he observed, crossed himself and wept at the sight of the Cathedral. Makarov believed that the Kalmyk was on his way to becoming an Orthodox Russian, and he anticipated that "the

6 I. G. Georgi, Opisanie vsekh obitaiushchikh $v$ Rossiiskom gosudarstve narodov (St. Petersburg: Imp. Ak. Nauk, 1776-1777), 3 Vols; Nathaniel Knight, "Constructing the Science of Nationality," 32-40; S. A. Tokarev, Istoriia Russkoi Etnografii (Moscow, Nauka, 1966), 103-110.

7 Tokarev, Istoriia Russkoi Etnografii, 103.

8 I. G. Georgi, Opisanie vsekh obitaiushchikh v Rossiiskom gosudarstve narodov (St. Petersburg: Imp. Ak.Nauk, 1799), 1: ix; Yuri Slezkine, "Naturalists versus Nations," 38-39; Nathaniel Knight, "Constructing the Science of Nationality," 36-39.

9 Yuri Slezkine, Arctic Mirrors: Russian and Small Peoples of the North (Ithaca, NY: Cornell University Press, 1994), 48-49. 
time will come when the light of Christ will dawn upon the wearer of the turban and the heathen."10

The conception of a Russian nation as a body with its own distinctive traits appeared in tsarist imagery and rhetoric with the accession of Nicholas I in 1825 and the propagation of the doctrine that came to known as "Official Nationality." The manifestos of the reign and the accompanying doctrinal literature established that the distinguishing feature of the Russian people was their monarchical spirit, their obedience to their sovereign, attested by the fact Russian people had not joined the rebels on palace square in December 1825. The decree on sentencing of the Decembrists of July 13, 1826 referred to Russia as a "state where love for monarchs and devotion to the throne are based on the native characteristics of the people."11 It was this spirit that had enabled the Russian people to resist revolutionary doctrines and had made Russia the strongest state in Europe after the Napoleonic Wars.

The triumphalist rhetoric of Nicholas I's reign extolled both the will of the tsar and the rapt discipline of his Russian subjects. That category comprised the mass of Russians without distinction between Little Russians, White Russians, Great Russians and others who had been assimilated into the official elite. The Ukrainian language was defined as a dialect of Russian, while Ukrainian folksongs and literature were viewed as expressions of an early Slavic culture that had been perfected by the Russians. ${ }^{12}$ The historian Mikhail Pogodin wrote, "Occupying an expanse that no other monarchy on earth has ever occupied, neither the Macedonian, nor the Roman, Arabic, the Frankish or the Mongol, it is settled principally by tribes who speak one language, have, consequently, one form of thought (obraz mysli), practice one Faith, and like an electronic circuit, quaver at a single contact." ${ }^{3}$ In Pogodin's formulation, the monarchy was identified with a Great Russian nation worshipful of its tsar, the nationalities serving at best as ornaments to its power and glory. The assimilation that enlightenment would wreak

10 M. N. Makarov, "Vospominaniia o koronatsii Imperatora Aleksandra I," Pamiatniki novoi russkoi istorii (1871), 1: 64, 75-79.

11 N. K. Shil'der, Imperator Nikolai Pervyi, 1:459.

12 See David Saunders, The Ukrainian Impact on Russian Culture, 1750-1850 (Edmonton: Canadian Institute for Ukrainian Studies, 1985), 144-75.

13 M. P. Pogodin, Istoriko-kriticheskie otryvki, 2. 
was presumed to continue under the rule of the dominant nation responsive to its tsar.

When defeats in the Crimean war dispelled the triumphalist certainty of Nicholas's scenario, Alexander II ushered in a mood of conciliation and openness and modified the discourse of official nationality to evoke the imagery of attraction rather than submission. The Russian people then were said to be bound to their ruler by the force of a love animated by gratitude for efforts at reform that he had selflessly enacted for their benefit. Alexander II presented himself as a popular national leader, incorporating democratic sentiments into the mythic narrative of Russian monarchy. The trope of love portrayed Russian monarchy as a romance between monarch and Russian people, joined willingly by the other nationalities of the empire.

These feelings were put on display at Alexander's coronation in 1856, which celebrated successes of imperial expansion in previous decades that compensated for the humiliating defeats of the Crimean War. In the context of a scenario of love, the nationalities were drawn into the mythical image of a nation adoring the sovereign. The emperor's coronation entry displayed the loyalty and submission of the peoples Russian armies had succeeded in conquering in the Caucasus, Central Asia, and Middle Asia. For the first time, their representatives marched in native costumes with members of the Russian elite. Accounts of the coronation exulted about the dashing horseman from the various Caucasian and Central Asian nationalities. The illustrated journal, Russkii Khudozhestvennyi Listok, described the deputies of "Asiatic peoples" as "tangible proof of the vastness of our state, which some justly call a special kind of planet." Their appearance in procession "eloquently convinced everyone of the one whose power they recognize, whom they had come from their own lands to greet." 14

The love of the Russian people for the sovereign was projected on the other peoples of the empire, as well, conjuring the vision of an empire united by mutual affection. The participation of Asian noblemen attested to their acceptance of the suzerainty of the Russian element in the empire. For the poet Fedor Tiutchev, who attended the ball as a chamberlain of the court, the masquerade expressed the Eastern character of Russia. It allowed him to imagine himself in the realm of dream-the dream of Russia's embracing the East. Tiutchev saw old aristocrats in familiar costume beside "quite authentic"

$\overline{14}$ Russkii Khudozhestvennyi Listok, No.29 (October 10, 1856), 1. 
Mingrelian, Tatar, Imeretian princes in magnificent costumes, and two Chinese. "And two-hundred steps from these halls resplendent with light and filled with this crowd that is so contemporary lay the tombs of Ivan III and Ivan IV." He wondered how they would react if they saw this scene. "Ah, how much dream there is in what belongs to reality," he wrote. ${ }^{15}$ Vasilii Grigor'ev, who was serving in Orenburg at the time of the coronation, arranged to have several Kirgiz deputies invited. In addition to the effect of their colorful costumes, he emphasized the "governmental significance" of their presence. "I have no doubt that this measure will be ten times more effective in instilling a favorable disposition towards and respect for Russia in the members of the [Kirgiz] horde than ten military expeditions to the Steppe and all possible circulars from the Commission." 16

The metaphor of love thus presumed that displays of reciprocal sentiments could dispose the nationalities to the monarchy and induce them to feel themselves part of an imperial nation. After Shamil's capture in August 1859, Alexander received him as a friend in public at balls and parades, as a living and willing trophy of conquest. When he met Shamil at the military camp at Chuguev, in Kharkov province, the newspaper, Syn Otechestva, reported that he embraced and kissed his captive and invited him to wear his sword during the review of troops at his side. Shamil's biographer wrote, "The former Imam, astonished by this tenderness, this soft, ineffably kind greeting, the like of which he had never heard, understood at this moment the true majesty of the mighty tsars...." The ruler of Russia "gave the wild man of the mountains a touching example of dealing with one's foe." Shamil later recalled the episode with tears in his eyes. ${ }^{17}$

15 I.S. Aksakov, Biografiia Fedora Ivanovicha Tiutcheva (Moscow: M. G. Volchaninov, 1886), 262-63; "Lettres de Th. I. Tjutsheff a sa seconde epouse née Baronne de Pfeffel," Starina i Novizna, XIX (1915): 160-61.

16 N. I. Veselovskii, V. V. Grigor'ev po ego pis'mam i trudam, 1818-1881 (St. Petersburg: A. Transhel', 1887), 146. I thank Nathaniel Knight for point out this citation.

17 Thomas M. Barrett, "The Remaking of the Lion of Dagestan: Shamil in Captivity," Russian Review 53, No. 2 (July 1994): 353-56; M. N. Chichagova, Shamil' na Kavkaze i v Rossii (St. Petersburg: S. Muller and I. Bogel'man, 1889), 107. See also Austin Jersild, Orientalism and Empire: North Caucasus Mountain People and the Georgian Frontier, 1845-1917 (Montreal and Kingston: McGill-Queen's University Press, 2002), 110-25. 
The most influential propagator of the image of a monarchy united with a conscious Russian nation was the editor of Moskovskie Vedomosti, Mikhail Katkov. In the wake of the Polish uprising, Katkov responded to the feeling of sympathy in educated society for the monarchy, by devising a new discourse of nationality. Andreas Renner has shown that he invented a "new method of 'patriotizing' thoughts and actions" and presented the nation "as an already established concept." He gave a name to a "political nationality" that "included other narodnosti with equal (except political) rights with a common national state." 18 But the state justified this authority, not through a national mandate, but through the ruthless and efficacious wielding of power that ensured its survival. Katkov urged the Russian armies in Poland to "aggressive and merciless action" and "to punish inexorably." At home, he believed in severe measures of state security. He wrote in 1863, "We somehow have forgotten that the sword is the symbol of the state, and the state is compelled to resort when necessary to strict and even severe measures." Katkov's answer to challenges to the monarchy was a dictatorship that would temporarily end the disturbances in society and even "hold back and slow down the normal development of the social and economic interests of the country." 19

Katkov developed the idea of the multi-national empire at one with the Russian nation in his articles in Moskovskie Vedomosti. In April 1863, he wrote, "There is in Russia one dominant nationality, one dominant language, which was developed by centuries of historical life." There were many tribes with different languages and customs, but they all felt a sense of unity with "the Great Russian world": "in the unity of the state, in the unity of the supreme authority in the Tsar, the living, sovereign, the personification of this unity." 20 Ivan Babst and Constantine Pobedonostsev, accompanying the heir, Nicholas Aleksandrovich, on his tour of the empire, described such sentiments in the pages of Moskovskie Vedomosti. At the governor's house in Astrakhan', Babst, Pobedonostev, and the Grand Duke marveled at the strange motley throng in national costumes, including Greeks, Armenians, Persians, Kalmyks, and Tatars. There were few Russian faces in the crowd, but

\footnotetext{
18 Andreas Renner, "Defining a Russian Nation," 676-77, 681.

19 V. A. Tvardovskaia, Ideologiia poreformennogo samoderzhaviia: M.N. Katkov i ego izdaniia (Moscow: Nauka, 1978), 27, 37-38.

20 M. N. Katkov, 1863 god; sobranie statei po Pol'skomu voprosu (Moscow: Moskovskie Vedomosti, 1887), 100-01.
} 
the three still felt themselves in Russia, "in one of the remote regions of a great tsardom, united by the powerful bond of state power and a consciousness of state unity." There, amongst the mixture of "dress, faces, and dialects," the basic tone was provided by the "founding and gathering element of the Russian tribe." 21

The precepts of enlightenment that informed the European myth of Russian autocracy presumed a propensity to assimilation among the subject peoples. Alexander II's scenario inspired projects to take advantage of this disposition by instilling concepts of citizenship (grazhdanstvennost ${ }^{\prime}$ ) in native leaders and intellectuals. The blueprint for these efforts was the Bashkir statute of 1865 , formulated under the direction of the Minister of War Dmitrii Miliutin. Jurists from several Ministries drafted the legislation, which was extended to Caucasus, Tartarstan, and Turkestan, as well as Bashkiria. Officials and generals now sought to spread ideas of citizenship by introducing reformed courts, local self-government, schools that would teach literacy, and open opera houses, museums and other purveyors of Russian and European culture. ${ }^{22}$

The existence of a propensity to assimilation, however, was belied by the realities of local power politics in the national regions. The officials who tried to impose the new civic order found their principles bent to the advantage of native elders who used the newfound autonomy to strengthen their own influence and promote opportunities for corruption. They sponsored their own appointees to local offices, created their own "political machines," and exacted "pay-offs" from local chiefs, which they could use to bribe the administration. ${ }^{23}$ The policy did produce leaders of the jadid movement, who sought to propagate a reformed version of Islam that could be incorporated into Russian imperial culture. The Tatar Ismail-Bey Gasprinskii, the Azerbeijani Hasan Melikov-Zardobi, and Munawwar Qari from Tashkent sought to spread an educational system that would create an enlightened, civically minded Islamic culture, compatible with Russian rule. But they found their efforts thwarted by

21 K. P. Pobedonostsev and I. Babst, Pis'ma o puteshestvii gosudaria naslednika tsesarevicha po Rossii ot Peterburga do Kryma (Moscow: Grachev, 1864), 356-57.

22 Dov Yaroshevskii, "Empire and Citizenship," in Russia's Orient, 69-71; Austin Lee Jersild, "From Savagery to Citizenship: Caucasian Mountaineers and Muslims in the Russian Empire," in Russia’s Orient, 101-14.

23 Yaroshevskii, "Empire and Citizenship," 71-73. 
tsarist officials who had little sympathy for local differences or autonomy and maintained traditional authoritarian practices. ${ }^{24}$

In the end, the monarchy remained trapped in its own mythology of conquest, which proceeded even as citizenship was touted. The Russian colonization of lands in the Caucasus and Central Asia, led by detachments of Cossacks, resulted in mass expulsions and extermination of native peoples, efforts that were countenanced by Miliutin himself, and opened territories for Russian peasants. ${ }^{25}$ Miliutin's military reform of 1874 , which presumably aimed at creating a citizen army, sought above all to preserve the existing system of estates and the subordination of national groups. ${ }^{26}$

The imagery of conquest and absolute domination could provide a means to integrate noble elites whose authority rested on a paternalistic ideology and who could share in the benefits of rule and a Western monarchical culture. But it could not accommodate native intellectuals who strove for a measure of national autonomy and toleration of cultural difference. The proffered embrace of the monarchy was rebuffed most powerfully by the Poles in 1863 , when the milder rule introduced by Alexander resulted in the slaughter of the sleeping Russian troops in Warsaw and open rebellion. The government's response was violent repression in Poland and the western provinces and the ruthless efforts of the Governor-General M. N. Murav'ev to Russify the western provinces. ${ }^{27}$ In Ukraine, the emergence of a national movement in literature belied the

24 Jersild, "From Savagery to Citizenship," 109-11; Edward J. Lazzerini, "Local Accommodation and Resistance to Colonialism in Nineteenth-Century Crimea," Russia's Orient, 169-87; Adeeb Khalid, "Representations of Russia in Central Asian Jadid," Russia's Orient, 188-202.

25 Peter Holquist, "To Count, to Extract, to Exterminate: Population Statistics and Population Politics in Late Imperial and Soviet Russia," in A State of Nations: Empire and Nation Making in the Age of Lenin and Stalin, ed. Ronald Grigor Suny and Terry Martin (Oxford: Oxford University Press, 2001), 116-21.

26 John S. Bushnell, "Miliutin and the Balkan War: Military Reform vs. Military Performance," in Russia’s Great Reforms, 1855-1881, 148-49, 154-56.

27 See Theodore R. Weeks, Nation and State in Late Imperial Russia: Nationalism and Russification on the Western Frontier (De Kalb, IL: Northern Illinois University Press, 1996); Mikhail Dolbilov, "Russification and the Bureaucratic Mind in the Empire's Northwestern Region in the 1860s," Kritika, New Series, 5, no. 2 (Spring 2004): 245-72; idem, "Konstruirovanie obrazov miatezha: Politika M. N. Murav'eva v Litovsko-Belorusskom krae v 1863-1865gg kak ob" ekt istoriko-antropologicheskogo analiza," in Actio Nova, ed. A. I. Filiushkin (Moscow: Globus, 2000), 338-408. 
image of a union of all the Russias obedient to the Tsar of Great Russia. The efforts of intellectuals to find a Ukrainian language threatened the belief in the ethnic unity of all the Russias, vital to the concept of a national empire. To Mikhail Katkov these efforts appeared outlandish. He wrote with disdain in 1863 , "There have recently appeared in the Ukrainian villages, in sheepskin caps, so-called disseminators of Little Russian literacy and organized Little Russian schools. There have appeared books in the newly fudged language. Finally, one famous professor has solemnly opened a nation-wide fund-raising subscription for publishing Little Russian books."28

A rift opened between officials such as Dmitrii Miliutin, who thought that punitive steps should be taken in Ukraine, and those sharing in Alexander's scenario, like the Minister of Interior Petr Valuev, who believed that assimilation could take place only by winning over public opinion to the imperial cause. Valuev was baffled by the dilemma of how to generate "centripetal and not centrifugal forces." He decided on mild measures, "light force" that would be assimilationist and civilizing. His circular, which he advanced reluctantly, banned religious and popular literature in the Ukrainian language. He believed that it would be temporary and could be revoked after the crisis of the Polish revolution. But it remained in force and brought an end to Sunday schools in the Ukrainian language and the attempts to publish Ukrainian primers and a Ukrainian version of the bible. ${ }^{29}$ The movement, however, persisted, prompting further repressive measures in the $1870 \mathrm{~s}$.

The scenario of love had been meant to obviate a system of popular representation. Alexander envisioned a unity of the estates with the monarchy in gratitude for the great reforms and the measure of freedom permitted after his accession to the throne. The first spurning of his embrace had been the noble constitutional movements of the early 1860s, which brought forth the emperor's angry reprimand. He declared that the reforms the government had introduced "sufficiently attest to my constant concern to improve and perfect, to the extent of possibility and in the order prescribed by me, the various branches of state administration." He insisted that the right of initiative for

\footnotetext{
28 Alexei Miller, The Ukrainian Question: Russian Nationalism in the Nineteenth Century (New York: Central European Press, 2003), 105.

29 Ibid., 210-12; Olga Andriewsky, "The Russian-Ukrainian Discourse and the Failure of the 'Little Russian Solution'," 1782-1917," in Culture, Nation, and Identity: The Ukrainian Russian Encounter (1600-1945), ed. Andreas Kappeler et al. (Edmonton: Canadian Institute of Ukrainian Studies, 2003), 210-13.
} 
reform belonged to him exclusively, "and is inseparably connected with the autocratic power, entrusted to me by God." His subjects did not have the right to anticipate his "incessant care for Russia's well-being... No estate has the right to speak with the name of other estates. No one can take it upon himself to petition me about the general welfare and needs of the state." 30 But rather than an upsurge of gratitude, Alexander's scenario brought forth disappointment, a sense of betrayal and anger, reflected in the growth of a revolutionary movement and finally the turn to terror that resulted in his assassination.

\section{National Myth and National Monarchy}

Alexander II's scenario of love fostered the presumption that increasing education and freedom would lead to increasing sympathy for the monarchy and a diminution of support for liberal and national programs. Both Valuev and Konstantin Pahlen, the Minister of Justice, clung to these presumptions as did many of the reformed officials in the administration. The assassination of Alexander II and the accession of Alexander III in March 1881 shattered these illusions and replaced them with the conviction that defense of the autocracy required the show and application of ruthless force. The new reign opened with the reaffirmation of a motif of conquest that ruled out conciliation and efforts at integration.

While measures of "Russification" had been taken during Alexander II's reign, they ill fit the dominant scenario of warm feelings and were pursued vigorously only in Poland and the western provinces of Russia. The elaboration of a "national myth," which presented the tsar as an ethnically Russian ruler, the most Russian of Russians, expressed a new militancy embodied in the figure of a burly, bearded, stolid tsar with firm resolve to forge an empire that was an ethnic Russian state. The manifesto of April 29, 1881, written by the tsar's mentor, Constantine Pobedonostsev, announced a new conception of autocracy. The bond between tsar and people was to be religious. The "Voice of God" had summoned the tsar "to turn vigorously to the task of Ruling, with hope in Divine Providence" after the shameful act of assassination. The use of the word "vigorously" (bodro) signified a revitalization of police authority. ${ }^{31}$

\footnotetext{
30 Terence Emmons, The Russian Landed Gentry and the Peasant Emancipation of 1861 (Cambridge: Cambridge University Press, 1968), 410-11.

31 PSZ, no. 118, April 29, 1881.
} 
The faith in God, the prayers of the people charged him to act with energetic and ruthless action from above. "Vigor" became a common term in the rhetoric of conservative periodicals calling for unyielding autocratic power.

The manifesto replaced the reign of Peter the Great preceded by "the invitation of the Varangians" with a new founding myth of Russian monarchy. Pobedonostsev wrote not of the Russian state or empire, but the "Russian land" (zemlia russkaia) evoking a neo-Slavophile picture of seventeenthcentury Russia as a period of harmony between tsar and people. The Russian land had been disgraced by vile sedition but with "hereditary tsarist power," continued to enjoy the love of its subjects, and this power "in unbreakable ... union with Our land" had survived such troubles (smuty) in the past. The historical paradigm now shifts from the Petrine empire, with its westernized multinational elite to a picture of idealized seventeenth-century polity, borrowed from the Slavophiles, when the tsar ruled in union and harmony with the Russian land.

The elevation and glorification of the monarch now took place by claiming to inhabit another time frame, when the Russian tsar was in contact with the nation. The synchronic mode was profoundly anti-traditional, expressing absolute rejection of the legacies of the recent reigns in the hope of resurrecting a distant past. The distance between the ruler and the ruled was the distance between him and the manifestations of the fallen present that encumbered his power. By exalting the seventeenth century, the national myth diminished the eighteenth and nineteenth, and delegitimized the legalistic bureaucracy, the intelligentsia, and the dynamic of reform that had reached its culmination in the previous reign. It looked back to a timeless heritage, untouched by historical change. The Russian emperor might live in Western palaces, consort with western royalty, and rule institutions with western names, but these superficial overlays concealed a national substratum (ustoi) that could be recovered through a restoration of the earlier political and spiritual order.

While Russifying initiatives succeeded only in certain areas of the empire, the prevalence of this ideology during the reigns of Alexander III and Nicholas II represented a powerful deterrent to the integration of nationalities throughout the empire. In place of a presumed assimilation into a multi-ethnic empire, the national myth presumed a preexistent national supremacy and dominance inherited from a distant and glorious past. In Ukraine, the western provinces, and Poland, it led to measures encouraging the spread of Orthodoxy and the Russian language. 
The building of Muscovite style churches in the national regions established the image of the empire not as a multi-national union of elites, but as a dominion of the Russian state. They were visual representations of an invented tradition of national domination that persisted since the sixteenth century that could deliver Russian from western liberal encumbrances by the measures introduced by an active and ruthless autocracy. Churches appeared as symbols of an empire dominated by ethnic, Orthodox Russians, rather than a multi-ethnic empire. They evoked images of a distant past of Orthodox religion and Russian rule, suggesting that the reproduction of the visual artifacts could restore the imagined unity of the earlier time.

Imposing orthodox churches displayed imperial rule over Central Asia. The Cathedral of the Transfiguration, a large neo-Byzantine church completed in 1888, towered over the governor's house on the principal square of Tashkent. It was the most prominent building in the center of the new Russian city. The buildings of the Teachers' Seminary in Tashkent were constructed in the 1880s in Muscovite style. In 1898, a tall five-cupola tentstyle brick church designed by A. L. Benois was built into the walls of the seminary compound, confirming the particular national and ethnic character of the Russian presence in Tashkent. ${ }^{32}$

Russian colonists and missionaries in the Caucasus expected "to restore" Orthodox Christianity, evoking a time when it was presumably the dominant faith in the region. Tent-style churches went up in Baku in the 1880s. Russian missionaries and officials in the Caucasus pointed out the importance of the physical presence of Orthodox churches for the religious guidance of the mountain peoples. The Viceroy of the Caucasus, Prince Alexander DondukovKorsakov wrote that the "external" aspects of the faith were most important for "Eastern peoples." 33

32 V. A. Nil'sen, U istokov sovremennogo gradostroitel'stva Uzbekistana: xix-nachalo xx vekov (Tashkent: Gafur Guliam, 1988), 49-52, 64-65; Robert Crews, "Civilization in the City: Architecture, Urbanism and the Colonization of Tashkent," in Architectures of Russian Identity: 1500 to the Present, ed. James Cracraft and Daniel Rowland (Ithaca, NY: Cornell University Press, 2003), 117-32.

33 Austin Jersild, "From Frontier to Empire: The Russification of the Caucasus, 1845-1917," unpublished manuscript, Chapter 4; A. Platonov, Obzor deiatel'nosti obshchestva vozstanovleniia pravoslavnago khristianstva na Kavkaze za 1860-1910 gg. (Tiflis: n.p., 1910). 
In the Baltic provinces and Poland, new churches and cathedrals ensured that the inhabitants would not forget who ruled their land. Cathedrals in Riga and Warsaw carried the name of Alexander Nevskii, Alexander III's namesake, and the traditional defender of Russia against Western Christendom. Publications celebrated their construction, providing conspicuous statements of domination. A large orthodox cathedral in Russian-Byzantine style had been built in the center of Riga from 1876-1884. ${ }^{34}$

The use of ecclesiastical architecture as a statement of symbolic conquest was most apparent in Warsaw, where almost twenty Russian-style Orthodox churches were built in the 1890s. In Warsaw, as in Riga, the MoscowByzantine style remained prevalent, signifying imperial domination. The principal cathedral, Leontii Benois' immense Alexander Nevskii Cathedral (1894-1912), combined the classical Moscow-Byzantine form with abundant kokoshniki covering on the roof affirming the national character of imperial rule. Its 70 meter bell tower made the Russian presence known by dwarfing surrounding buildings. It became "the most conspicuous accent of the city skyline," prompting lewd comparisons from the city's residents. ${ }^{35}$ Initiative belonged to the Governor-General, I. V. Gurko, who solicited contributions from Russian donors. The chancellery of the Governor-General appealed to residents of Moscow: "By its very presence ... the Russian Church declares to the world ... that in the western terrains along the Vistula, mighty Orthodox rule has taken root.... The appearance of a new ... church in Warsaw as a boundary and pillar of Orthodox Russia will animate the hopes of the Orthodox Slavs for unification under the Orthodox cross." The journal of the Warsaw Eparchy boasted in 1912, "Under the dome of this magic temple, we find ourselves as if on Russian soil." 36

Authorities pressed colonization of land in the Caucasus and Turkestan by Russian peasants, regardless of the resistance of native elites. Although Russian peasants proved ill-suited to colonization, and local officials preferred farmers of other nationalities, such as Armenians, Greeks, Moldavians, and Czechs,

\footnotetext{
34 Riga und seine Bauten (Riga: P. Kerkovius, 1903), 181-84.

35 Piotr Paszkiewicz, "The Russian Orthodox Cathedral of Saint Alexander Nevsky in Warsaw," Polish Art Studies 14 (1992): 64-65, 67.

36 Ibid., 65-66; for a more detailed discussion of revival church architecture see my article, “The Russian Style' in Church Architecture as Imperial Symbol after 1881,” in Architectures of Russian Identity, 101-116.
} 
the government endeavored to grant permissions and subsidies only to Russian peasants. The policy of discrimination in the Caucasus, an official paper argued, "was necessary for the strengthening of the Russian element amid the different and not always reliable nationalities in order to raise the prestige of Russia [and] its faith, language, and civilization in the region." 37 The relationship that prevailed at the local level is well illustrated by the inaugural ceremony of Governor-General A. N. Kuropatkin held in Ashkabad of the Transcaspian Region in 1890. When welcomed by an Armenian merchant, he retorted angrily that the delegations should be rearranged. The Russians from the townspeople estate (meshchane), he declared, should be placed in front, then the Turkmen and Kirgiz, then Christians, including the Armenians, finally the foreigners, Persians, and Afghans. The Russian townspeople, though representing a lesser estate, had to appear as the leading delegation in the local hierarchy. 38

The national myth framed new policies to exclude Jews from the national body, in contrast to the relative tolerance of the previous reign. The appeal to ethnic identity and rejection of the western character of the autocracy encouraged the exclusionist image of the Jew not only as alien, but an enemy of the Russian nation. Beginning with the pogroms of 1881, the government sought to reverse the effects of the reforms, introducing limits on Jewish residence, and restrictions of admissions to the universities and the bar. ${ }^{39}$ The monarchy endeavored to cleanse Moscow, the symbolic center of the national autocracy, of Jews. ${ }^{40}$ When Grand Duke Sergei Aleksandrovich assumed the office of Governor-General of Moscow in 1891, he asked, with the tsar's support, that the Jews be removed, leading to brutal expulsions of two-thirds of the city's thirty thousand Jewish residents.

Most fundamentally, the new national symbolic increasingly precluded the possibility of national groups, either the religious hopes for conversion or the secular visions of enlightenment, which had been conflated. Despite the rhetoric and imagery of Russification, the discourse increasingly emphasized

\footnotetext{
37 Jersild, Orientalism and Empire, 126-29, 138-40.

38 Yaroshevskii, "Empire and Citizenship," 58-59.

39 On the "selective integration" of Jews in the second half of the nineteenth century and the setbacks during the 1880 s, see Benjamin Nathans, Beyond the Pale.

40 On the shift from Petersburg to Moscow as the symbolic center of empire see article 8 .
} 
permanent, even racial, attributes of national identity, reflected in a shift in the terminology for other nationalities, from inovertsy-peoples of other religions-to people of other ethnic stock, inorodtsy, or aliens. Russian law had included only Jews and nomads in the category inorodtsy, groups considered so alien to the Russian social system that they could not be assimilated. But in the last decades of the nineteenth century, the term began to be applied to all non-Russian nationalities and to express ethnic differences that implicitly precluded assimilation. ${ }^{41}$

This shift that took place in official discourse also reflected the emergence of a popular Russian national vision of a Russian land that would engulf and even extend the empire. The line between metropole and periphery is the standard term now in use in the literature on empires. Russian explorers and nationalist thinkers, like Nicholas Danilevskii, viewed the southern steppe and the Asian borderlands as destined for Russian colonization, territories virtually empty and ready for occupation that could provide an answer to the land hunger prevailing in the Russian interior. In 1892, the eminent explorer-geographer Petr Semenov described Russia’s mission as "part of the great colonizing movement of the European race," comparable to the overseas colonization of Spain, France, and England. ${ }^{42}$ Semenov's fellow explorer and geographer, Mikhail Veniukov, who believed that the autocracy was the principal deterrent to the formation of a nation state, declared in a speech of 1873 that the endurance and courage of Russian soldiers not only defeated the native peoples, but ensured that "the Caucasus became Russian land." They triumphed in a region where "without the arrival of Russians barbarism

$\overline{41}$ See Paul Werth, "Changing Conceptions of Difference, Assimilation, and Faith in the Volga-Kama Region, 1740-1870," in Russian Empire: Space, People, Power, 1700-1930, 171-88; John W. Slocum, "Who, and When, Were the Inorodtsy? The Evolution of the Category of 'Aliens' in Imperial Russia," The Russian Review 57 (April 1998): 173-90; on the complexities of the usage of the term in Muslim regions, see V. O. Bobrovnikov, "Chto vyshlo iz proektov sozdaniia v Rossii inorodtsev? (Otvet Dzhonu Slokumu iz musul'manskikh okrain imperii)," Poniatiia o Rossii, 2: 259-91.

42 Cited in Uillard Sanderlend (Willard Sunderland), "Imperiia bez imperializma?" in I. Gerasimov, et al., ed. Novaia Imperskaia Istoriia Post-Sovetskogo Prostranstva (Kazan: Tsentr Issledovanii Natsionalizma i Imperii, 2004), 463. See also my article, "Russian Noble Officers and the Ethos of Exploration," 181-97; Vera Tolz, Russia: Inventing the Nation, 170-74. 
would rule forever." 33 In literature and history the Russian land became an expression and metaphor for the Russian nation, a kind of surrogate for parliamentary bodies representing a political nation. In his popular Course of Russian History, Vasilii Kliuchevskii wrote that colonization was "the basic fact of Russian history" and that "the history of Russia is the history of country that colonizes itself." 44

The erection of daunting Muscovite edifices, the evocation of an imagined Russian national empire, and the spread of an ethos of colonization, however, only revealed the rift between the imagery and ideology of the monarch and its adherents and the subject nationalities of the empire. The rift became evident with the established of the State Duma and elections of 1906, which led to the formations of native elites who organized political parties seeking national rights and autonomy. ${ }^{45}$ The new institutions produced a heightening of tensions between Russians and national groups and led to conflict rather than reconciliation or efforts at integration. In Bashkiria, where Russians and Bashkirs had reached a modus vivendi with local elites, a "language of patriotism began to penetrate local political life" that was expressed in widelycirculated chauvinistic pamphlets. ${ }^{46}$ At the same time, those Tatars in Kazan who succeeded in assimilating Russian culture or converted to Orthodoxy met with aversion from Russians, whose sense of nationality was threatened by natives, who did not resemble them. ${ }^{47}$

The first Duma consisted of only 58.5\% Russian delegates (including Ukrainians and White Russians), challenging the Russian domination of empire. ${ }^{48}$ S. E. Kryzhanovskii, then an official in the Minister of Interior who was formulating the electoral laws, had foreseen the problems:

43 M. I. Veniukov, Iz vospominanii: kniga pervaia, 1832-1867 (Amsterdam: n.p., 1895), 336-38. The memoirs were written in the 1880s when Veniukov was living abroad.

44 Willard Sunderland, Taming the Wild Field, 177-220.

45 Rustem Tsiunchuk, "Peoples, Regions, and Electoral Politics: The State Dumas and the Constitution of New National Elites," in Russian Empire: Space, People, Power, 1700-1930, 366-97; Elena Campbell, "The Muslim Question in Late Imperial Russia," in ibid., 330-43.

46 Charles Steinwedel, “To Make a Difference: The Category of Ethnicity in Late Imperial Politics, 1861-1917," in Russian Modernity: Politics, Knowledge, Practices, 76-77.

47 Robert P. Geraci, Window on the East: National and Imperial Identities in Late Tsarist Russia (Ithaca, NY: Cornell University Press, 2001), 309-51.

48 Tsiunchuk, "Peoples, Regions, and Electoral Politics," 387. 
In Russia, the predominant nationality (natsional'nost') on which the government stands comprises only about 66 percent of the overall population, and alien nationalities (chuzhye narodnosti) 34 percent, that is a percentage not seen in a single Western European power other than Austria ... Therefore the interests of the greatest state importance urgently require that the voice of the Russian people, upon whom both the strength of state authority and the very throne of the Russian sovereign depend, unconditionally prevail in institutions concerned with the preparation of legislation ... A strong majority inconvenient for the government may form in the Duma on questions touching on the interests of non-Russians. ${ }^{49}$

On June 7, 1907, Stolypin perpetrated his coup d'état, a change in the election laws under the tsar's emergency powers, which curtailed the representation of urban populations and enhanced that of the nobility. The law also assured Russian domination of the Duma by sharply reducing the number of deputies elected by Poles, Tatars, and Armenians and excluded representatives from Turkestan. The rhetoric of the manifesto made clear that tsar and government viewed the state as Russian, and the nationalities as alien to the body politic. Nicholas declared that the Duma, "created for the strengthening of the Russian State (Gosudarstvo Rossiiskoe), must be Russian (russkii) in spirit as well." Other nationalities should have "representatives of their needs in the State Duma, but not in numbers allowing them to decide questions that are purely Russian." Elections were temporarily ended in those border regions "where the population has not attained a sufficient level of civic development." 50 Of the delegates to the Fourth Duma, 83.4 percent were Russians.

The tsar and prime minister agreed on the need to maintain Russian national dominance: neither favored compromise or conciliation with the nationalities. But they maintained completely irreconcilable conceptions of Russia. The manifesto conflated the meanings of "Rossiia" and "Rus', but whereas Stolypin identified Rossiia with the empire in the form of a modern nation-state, Nicholas looked to a resurrection of the spirit and traditions of ethnic Rus', which he understood as a bond between himself and the Russian people, which predated Peter's westernized empire and was exemplified in an idealized image of the reign of Alexei Mikhailovich.

49 Cited in Tsiunchuk, "Peoples, Regions, and Electoral Politics," 369.

50 PSZ, Sobranie 3, no. 29240, June 3, 1907; Tsiunchuk, "Peoples, Regions, and Electoral Politics," 387. 
This bond was personal, displayed in ceremonial meetings at the great historical celebrations staged from 1909 to 1913, where scenes of mutual devotion between Nicholas and the army and Nicholas and the peasantry inspired in him a sense of mystical exaltation. The bicentenary of the battle of Poltava in 1909, the centenary of the battle of Borodino in 1912, and the tercentenary of the election of the first Romanov tsar in 1913, transformed these great historical triumphs of early centuries into episodes in Nicholas's scenario. Representatives of the conservative-dominated Duma were either excluded or assigned secondary roles. For the tsar, Russia was represented by the army-the instrument and symbol of conquest that had crushed the revolutionary movement-and the Russian peasants, who he believed remained devoted to him despite the peasant uprisings of 1905 and 1906. The parades at the Poltava and Borodino celebrations provided occasions to display the strong, comradely rapport that Nicholas felt with the officers and troops of his military. At all three celebrations, he was cheered by masses of peasants. He chatted with groups of peasants and claimed to feel bonds of sympathy and friendship that he did not experience with the educated and privileged.

The emperor's and the empress's trip along the Volga in May, 1913 was the culmination of the Tercentenary celebration and a display that Nicholas regarded as amply demonstrating his bond with people. Their visits to churches and veneration of local icons along the away enhanced their sense of closeness to Moscow and distance from the present. Sailboats covered with flags greeted them. At the prompting of the Ministry of Interior, scenes and ceremonies of welcome took place along the river banks. Villages put up triumphal arches decorated with plants and the words "God Save the Tsar." Peasants gathered in camps stood on the shore and even ventured into the river up to their waists to see the tsar. As the flotilla approached each town, church bells sounded, and priests led processions of the cross from their churches to banks, where they blessed the ships. Peasants knelt, crossing themselves, and shouted, many with tears, "God protect the little father tsar (batiushka-tsar')."

In Kostroma, the original Romanov patrimony, Nicholas was blessed by the Icon of the Fedorov Mother of God that had been used to bless Tsar Michael Fedorovich in 1613. Atop the town pavilion, Nicholas was greeted with a thunderous "hoorah" and an ovation from the crowd. A regimental band gave a show of marches to tunes from $A$ Life for the Tsar. When the moment came to sing the tsarist anthem, the crowd sank to their knees. As Nicholas stood before the thousands of kneeling peasants, his eyes moistened. 
Those present also felt moved, convinced that this was a significant show of popular devotion for the tsar. In Moscow, a similar scene was enacted on Red Square, before mass of shouting peasants. While political conflicts marred Nicholas's visits to both Kostroma and Moscow, Nicholas returned to Tsarskoe Selo convinced that he made contact with the Russian nation. He declared that his trip to the Volga and old Russian towns "has proved once more that the bond between Tsar and people that distinguished our Mother Russia in olden times exists indestructibly now as well." 51

The historical celebrations were accompanied by a campaign of mass publicity, which reached its culmination during the Tercentenary events that sought to popularize Nicholas's image and sustain the impression that he enjoyed mass support. Pictures of the tsar and the imperial family appeared on new postage stamps, commemorative coins, and kitsch, the souvenirs of celebrations. Films acquainted a mass public with scenes of the imperial family at ceremonies and episodes from Russia's past. Articles in the press and a widely circulated official account of Nicholas's life acquainted a growing reading public with his habits, tastes, and ostensibly democratic predilections. ${ }^{52}$

At the same time, Nicholas sought to embody the image of a Muscovite tsar, inhabiting an imaginary landscape of seventeenth-century Rus', where the tsar enjoyed absolute power and lived in harmony with his subjects. At Tsarskoe Selo, he and Alexandra created a replica of an early Russian town, the Fedorovskii gorodok, built for the tsar's personal convoy and his sharpshooter regiment. The centerpiece was the Fedorov Cathedral, (1908-1912) dedicated to the Fedorov Mother-of-God-the protectress of the dynasty. The official name of the church, Fedorovskii Gosudarev Sobor, The Sovereigns' Fedorov Cathedral, made it clear that it was the domain of the tsar and tsaritsa.

The architect, Vladimir Pokrovskii, designed the cathedral in the spirit of the neo-Russian school, which sought sources of inspiration for a reborn national architecture in all periods of early Russian architecture. Pokrovskii took the model of the fifteenth-century Annunciation Cathedral in the Kremlin, which had served as the private chapel of the Moscow tsar's family, but attached tent-shaped roofs over the main entrance and the covered

51 Moskovskie Vedomosti, May 26, 1913, 2.

52 See my article, "Publicizing the Imperial Image in 1913," in Laura Engelstein and Stephanie Sandler, eds., Self and Story in Russian History (Ithaca: Cornell University Press, 2000), 94-119. 
vestibules adding flamboyant elements recalling seventeenth-century churches. He also drew on Novgorod motifs for the bell tower. In this respect, the church created its own esthetic that erased the historical and stylistic distinctions of early Russian architecture and strove for a contemporary esthetic true to the past rooted in a popular spirit.

The town was to represent a spiritual model of a reborn nation, taken from Russia’s distant past. Stepan Krichinskii designed a Kremlin with walls and towers of elaborately decorated white Staritskii limestone. Krichinskii and other architects of neo-Russian style favored the form of Kremlin walls, which emphasized the separation of the church and the town from the outside world. If the models for Alexander III's official Russian style were urban churches in popular style like Vasilii the Blessed and Moscow-Iaroslavl churches, the models for Nicholas II's were old Russian monasteries, sequestered by walls from intrusion. The purpose was not admonitory but exemplary, showing the survival and revival of old Russian piety by those foreswearing the contestation and distractions of modern society.

Nicholas's historical imaginings lent his scenario an aspect of fantasy and make-believe alien to previous imperial presentations. But he clearly believed that the roles reflected his national self, and he came away from these appearances with a heightened sense of mission and determination to restore pure autocracy. As a result, in the opening years of the twentieth century we witness the collision of two violently opposed insurgent forces, a Russia awakening politically and demanding to be heard and a monarch seeking, through the punitive means at his disposal, to create a pure autocracy where a tsar drew personal authority from God and the people, unencumbered by institutions of state.

It is clear that, in this epic struggle for Russia's political destiny, neither side sympathized with the cause of the integration of the nationalities into the empire. Both the leaders of the non-socialist parties and the monarch looked to the emergence of a nation state dominated by ethnic Russians. Meanwhile, national movements emerged that strove for autonomy within the empire. In the political circumstances and culture of the time, these aspirations could be resolved only in the spirit of conflict, with the clash of the antinomies, rebellion and submission, taking precedence over hopes for integration and acceptance. 